\title{
SECURITIES: THE USAGE TO A LENDING BANKER
}

\author{
Akinyemi Balogun \\ Mamidu A. Ishola \\ College of Social and Management Sciences (COSMAS) Achievers \\ University, Owo, Ondo State
}

Doi: 10.19044/elp.v1 no1a5 URL:http://dx.doi.org/10.19044/elp.v1no1a5

\begin{abstract}
This paper researched into why provision of collateral security by a bank customer is not a $100 \%$ guarantee that facilities sought for would be granted. The prerequisite for granting facilities includes: Good Characterintegrity, strong financial Capacity, repayment proposal, the purpose of the loan, the Ratio/Proportion of the loan/facilities sought-for to that of the security offered. The lending banker should also consider: relevant accounting ratios. The real security is the integrity of the borrower; lending proposition must be so good that the question of security becomes secondary
\end{abstract}

Keywords: Bank customer, Securities, Lending Banker and Facilities

\section{INTRODUCTION}

The development of commercial activities in any economy depends largely on the financial sector that operates in that system. Banking sector constitutes one of the bodies in financial sector. Best (1989) defined a banker as a dealer in capital, or more properly, a dealer in money. He is an intermediate party between the borrower and the lender. He borrows off one party and lends to another.

The above definition places a lot of emphasis on the two traditional functions of banks i.e. mobilization of deposits and granting of loans and advances. Skye bank Plc was set up like other commercial banks in Nigeria to grant short term loans to customers and keep their customers' deposits in save custody. Skye bank Plc extends its facilities (loans and advances) to sole proprietors, partnership, Limited Liability Companies and expatriate groups. During the process of lending to customers, the lending banker is expected to obtain satisfactory answers to some basic questions which are described as canons of lending. Some of these canons are: How much does the customer want to borrow?, why does the customer want bank finance? 
and how long does the customer want it for?. Others are: how does he intend to repay?, is the customers' business financially strong enough to keep going if customers' business plans suffer a setback?, what security can the customer offer? and what is your assessment of the customer?

Over the years, the bank had maintained that security is secondary in the process of lending. The past transactions of the prospective borrowers and his accounts with the bank as well as its financial statements are well scrutinized before facilities are approved for the customers.

Some borrowers have the wrong notion that security is the primary pre-requisite for securing loan/facilities from a lending banker. Many propositions had suffered rejections from lending banker even after customers had struggled to provide adequate securities! It is therefore necessary to delve into:

1. Why Banks ask customers to bring securities before loan facilities are granted (if at all the loan would be granted).

2. The prerequisites for granting loans/facilities by a lending banker.

With this research, it is believed that both individuals and corporate bodies alike would be able to know the pre- requisites for approving loan/facility to customers. Hence, they would be able to appraise themselves even before getting to the banks to seek for facilities.

\section{LITERATURE REVIEW}

Layi and Afolabi (1990) were of the opinion that lending is to identify, measure and manage risk and that a critical analysis of the above factors should provide sufficient basis for lending decision-making. Several studies have been carried out on securities and the lending banker. Layi and Afolabi (1990) in their work on Law and Practice of Banking were of the opinion that 'Security is an insurance against unforeseen developments and the last source through which the bank can get its money recouped should things turn sour'. It is a general opinion in the banking parlance that security should not be the primary thing to consider when facilities are requested by a customer from the lending banker. Preferential creditors rank before other creditors in respects of the security pledge; security (CAMA; 2004: Section 498) can even be set aside if created within three months of commencement of winding - up proceeding of a company. David (1981) maintained thatEvery lending proposition 'should be up by itself.' - i.e. it should be so good enough not to need any security. Perry (1979) in his work supported David (1981) when he wrote that security is taken as a kind of insurance. The real security is the character - integrity of the borrower. Adekanye (1986) crowned the aforementioned writers' view since he was of the opinion that every lending proposition must be so good that the question of security becomes secondary. It was his opinion that the primary things to consider by 
a lending banker are safety, suitability and profitability of the loans and that securities are secondary. Hence, of what use are securities to the lending banker?

Femi Adekanye (1986) provides answer to the above question in his work. He maintained that bankers only asks for security or support in case the business plans suffer a setback and the loan goes bad or becomes doubtful of repayment. Layi and Afolabi (1990) in their 'Law and Practice of Banking' were of the opinion that: 'The general consensus is that, the best form of bank security is the ability and integrity of the borrower; such that the bank can expect to be repaid as and when due and in the ordinary course of business'.

After the integrity of customers has been known and what the loan is meant for is okay, the next step is the interpretation of the customers' accounts. The emphasis is usually on a critical evaluation of the proposal using the lending cannons mnemonically referred to as the "C"s of lending, which are: capital, capability, character, condition and connection (Layi \& Afolabi. 1990; 232). This will reveal the customers' business profitability and efficiency, short term solvency/ liquidity ratio and the long term solvency/ stability ratio.

\section{RESEARCH METHODOLOGY}

For effective and efficient data collection procedures, two main instruments were used namely: questionnaire and personal interview. All members of Loans \& Advances department and some staff who have worked in the department before were given questionnaire each for completion. The entire questionnaires were personally administered. Some members of staff who were fully involved in the appraisal of customers' applications by means of financial analysis were interviewed. The research concerns itself with a case study of Skye Bank PLC, Owo Branch. So the population of study comprises the entire staff of Skye Bank PLC, Owo Branch. The entire population was then divided into strata. The strata were made up of: Loans/Advances, Foreign Accounts, Current Accounts and Savings Accounts Department.

Each questionnaire was divided into three sections - A, B and C. Section A inquires about personal data of the respondents. Section B dealt with the canons of lending. Finally, section $\mathrm{C}$ concerns itself with the assessment of customers, the importance of accounting ratios in lending procedure and the Demerits of securities to the lending banker. Closed and multiple choice type of questions were used.

\section{III.i HYPOTHESES}


In this research work, two hypotheses were employed. These hypotheses are:

Hypothesis 1. Ho: The customer has no wiliness to repay loan

H1: The customer has the wiliness to repay loan

Hypothesis 2. H0: The customer has no capacity to repay loan

H1: The customer has the capacity to repay loan

\section{III.ii ANALYTICAL TECHNIQUE}

Chi-square statistical tool was used in testing the hypotheses raised in this research; whereby 'the observed frequency' was compared with the 'expected frequency' so as to bring out the acceptability of the hypotheses raised or otherwise. The following mnemonics would be used: $\mathrm{O}=$ Observed frequency; $\mathrm{E}=$ Expected frequency; Chi-square $\left(\mathrm{X}^{2}\right)=\underline{(\mathrm{O}-\mathrm{E})^{2 \mathrm{E}}}$

The observed frequency was the direct response from the respondents, while 'expected frequency' was the theoretical frequency/result which shows how the observed frequency would have been. The expected frequency is calculated directly from the observed frequency using the following formula:

Expected $=(\underline{\text { Row Total } x \text { Column Total }})$

\section{Grand Total}

$X^{2} t=$ Critical value from the Statistical Table and $X^{2} c=$ the value computed from the table of data collected.

In analyzing the data, simple Mathematical methods of comparison and Percentages were used. The data collected were analyzed in tabular form.

\section{DATA ANALYSIS AND INTERPRETATION OF RESULT}

Best and Kahn $(1989 ; 141)$ advised that a researcher should use the problems generated from the study and generate convenient hypotheses; and that a data summary table should be obtained to justify the result. Hence, this section is devoted to data summary table, justification of result and testing of the hypotheses raised.

\section{A - Canon of Lending}

Please rank the following statements - canon of lending by assigning values from 0 to 5 to indicate their relative importance to the lending banker.

TABLE I: ANALYZING THE CANONS OF LENDING

\begin{tabular}{|c|c|c|c|c|c|c|c|c|}
\hline $\mathbf{S} / \mathbf{N}$ & STATEMENTS & \multicolumn{6}{|c|}{ VALUES } & TOTAL \\
\hline & & $\mathbf{0}$ & 1 & 2 & 3 & 4 & 5 & \\
\hline 1. & $\begin{array}{l}\text { The amount which the } \\
\text { customer want }\end{array}$ & - & - & - & - & 5 & 15 & 20 \\
\hline 2. & The capital of the customer & - & - & - & - & 2 & 18 & 20 \\
\hline
\end{tabular}




\begin{tabular}{|c|c|c|c|c|c|c|c|c|}
\hline 3. & The capability of the customer & - & - & - & 2 & 2 & 16 & 20 \\
\hline 4. & The character of the customer & - & - & - & - & - & 20 & 20 \\
\hline 5. & Condition of the customer & - & - & - & 1 & 2 & 17 & 20 \\
\hline 6. & $\begin{array}{c}\text { Connection at the reach of } \\
\text { borrower }\end{array}$ & - & - & - & - & 2 & 18 & 20 \\
\hline 7. & The security the borrower has & & - & 15 & - & - & 5 & 20 \\
\hline 8. & Period of repayment & - & - & - & - & 2 & 18 & 20 \\
\hline 9. & The purpose of the loan & - & - & - & - & 4 & 16 & 20 \\
\hline
\end{tabular}

Sources: Researcher's field work

Table I shows the relative importance of using canon of lending in granting loan to customer. From the above table $75 \%$ of the respondents were of the opinion that the amount of loan which the customers want is of importance to the lending banker while $90 \%$ believed that the capital worth of the borrower's business is of importance to the banker. Considering capacity and character of the customer, $80 \%$ and $100 \%$ respectively subscribed to the fact that they are of importance to a lending banker. During the course of analyzing the data collected $85 \%$ and $90 \%$ is of the opinion that condition (state of the economy) and connection respectively are of importance to the banker. Analyzing the table further, the result revealed that only $25 \%$ of the respondents believed that security is of importance to a banker. Finally, $90 \%$ and $80 \%$ believed that the period of repayment and the purpose of the facility respectively are of importance to the banker.

\section{B. - Accounting Ratios}

Please rank the following Accounting Ratios by assigning values from 0 to 5 to indicate their relative importance to the lending banker to evaluate the customers' statement of comprehensive income and financial position so as to determine their financial strength.

TABLE II: Accounting Ratio Analysis

\begin{tabular}{|c|c|c|c|c|c|c|c|c|}
\hline S/N & RATIOS & \multicolumn{5}{|c|}{ VALUES } & TOTAL \\
\hline & & $\mathbf{0}$ & $\mathbf{1}$ & $\mathbf{2}$ & $\mathbf{3}$ & $\mathbf{4}$ & $\mathbf{5}$ & \\
\hline 1. & Current ratio & - & - & - & - & 2 & 18 & 20 \\
\hline 2. & Liquidity ratio & - & - & - & - & 2 & 18 & 20 \\
\hline 3. & Stock Turnover ratio & - & - & - & 2 & 2 & 16 & 20 \\
\hline 4. & Gross Profit ratio & - & - & - & - & 4 & 16 & 20 \\
\hline 5. & Net Profit ratio & - & - & - & & 3 & 17 & 20 \\
\hline 6. & Return on capital employed - & - & - & - & - & 2 & 18 & 20 \\
\hline 7. & ROCE & & & & & & & \\
\hline 8. & Earnings Per share - EPS & & - & - & - & 5 & 15 & 20 \\
\hline 9. & Earning yield & - & - & - & 4 & 2 & 14 & 20 \\
\hline
\end{tabular}

Sources: Researcher's field work 
Table II shows the relative importance of using accounting ratios in evaluating customers' financial strength. From the above table $90 \%$ of the respondents were of the opinion that current ratio is of importance to the banker in evaluating customers' financial position. Considering liquidity ratio and stock ratio of the customer, $90 \%$ and $80 \%$ respectively subscribed to the fact that they are of importance to a lending banker. During the course of analyzing the data collected $80 \%$ and $85 \%$ were of the opinion that gross profit ratio and net profit ratio respectively were of importance to the banker. Analyzing the table further, the result revealed $80 \%$ and $75 \%$ were of the opinion that returns on capital employed and earnings per share respectively were of importance to the banker. Finally, 90\% and $80 \%$ believed that earning yield and gearing ratio of the customers' business respectively were of importance to the banker.

\section{C. - The Hypotheses}

TABLE III: Chi-Square Contingency Table used HYPOTHESIS NO. 1

HYPOTHESIS NO. 2

\begin{tabular}{|c|c|c|c|c|c|c|c|c|c|}
\hline $\begin{array}{c}\mathbf{O} \\
O B S E R \\
V E D\end{array}$ & $\begin{array}{c}\mathbf{E} \\
E X P E C T \\
E D\end{array}$ & $\mathbf{O}-\mathbf{E}$ & $(\mathbf{O}-\mathbf{E})^{2}$ & $\frac{(\mathbf{O}-\mathbf{E})^{2}}{\mathrm{E}}$ & $\begin{array}{c}\mathbf{O} \\
\text { OBSERVED }\end{array}$ & $\begin{array}{c}\mathbf{E} \\
\text { EXPECTED }\end{array}$ & $\mathbf{O}-\mathbf{E}$ & $(\mathbf{O}-\mathbf{E})^{2}$ & $\frac{(\mathbf{O}-\mathbf{E})^{2}}{\mathrm{E}}$ \\
\hline 4 & 6 & (2) & 4 & 0.67 & 3 & 3 & 0 & 0 & 0.00 \\
\hline 7 & 5 & 2 & 4 & 0.80 & 5 & 5 & 0 & 0 & 0.00 \\
\hline 6 & 4 & 2 & 4 & 1.00 & 3 & 4 & $(1)$ & 1 & O.25 \\
\hline 2 & 4 & (2) & 4 & 1.00 & 4 & 7 & (3) & 9 & 1.29 \\
\hline 1 & 0.6 & 0.4 & 0.16 & 0.27 & 2 & 2 & 0 & 0 & 0.00 \\
\hline 0 & 0.5 & $(0.5)$ & 0.25 & 0.50 & 3 & 3 & 0 & 0 & 0.00 \\
\hline 0 & 0 & 0 & 0 & 0.00 & 0 & 0 & 0 & 0 & 0.00 \\
\hline 0 & 0 & 0 & 0 & $\underline{0.00}$ & 0 & 0 & 0 & 0 & $\underline{0.00}$ \\
\hline \multicolumn{4}{|c|}{$\mathrm{X}^{2} \mathrm{c}$ TOTAL $=$} & $\underline{3.74}$ & & $\underline{1.54}$ \\
\hline
\end{tabular}

TABLE IV: TESTING THE HYPOTHESES

(Summary of the Hypotheses)

\begin{tabular}{|c|c|c|c|c|c|}
\hline S/N & HYPOTHESIS & $\begin{array}{c}\mathbf{X}^{2} \mathbf{c} \\
\text { Computed }\end{array}$ & $\begin{array}{c}\mathbf{X}^{2} \mathbf{t} \\
\text { Table }\end{array}$ & D.F & LEVEL OF SIG. \\
\hline $\mathbf{1 .}$ & $\begin{array}{c}\text { Hypothesis 1 } \\
\text { H0: The customer has no willingness to repay loan } \\
\text { H1: The customer has willingness to repay loan }\end{array}$ & $\mathbf{3 . 7 4}$ & $\mathbf{7 . 8 1}$ & $\mathbf{3}$ & $\mathbf{0 . 0 5}$ \\
\hline $\mathbf{2 .}$ & $\begin{array}{c}\text { Hypothesis 2 } \\
\text { H0: The customer has no capacity to repay loan } \\
\text { H1: The customer has capacity to repay loan }\end{array}$ & $\mathbf{1 . 5 4}$ & $\mathbf{7 . 8 1}$ & $\mathbf{3}$ & $\mathbf{0 . 0 5}$ \\
\hline
\end{tabular}

Sources: Fromm Researcher's Chi-Square Contingency Table 
INTERPRETATION OF RESULT: The tables above ((Tables III \& IV) showed the Chi-square contingency tables to test the two hypotheses raised for the study. Namely

Hypothesis 1. Ho: The customer has no willingness to repay loan

$\mathrm{H} 1$ : The customer has the willingness to repay loan

Hypothesis 2. H0: The customer has no capacity to repay loan

H1: The customer has the capacity to repay loan

- On Hypothesis 1

The Chi - square computed $\left(\mathrm{X}^{2} \mathrm{c}\right)$ from the respondents to the questionnaire in the above Chi-Square Contingency Table was $\mathbf{3 . 7 4}$ for hypothesis 1; while the Chi - square from the Statistical table $\left(\mathrm{X}^{2} \mathrm{t}\right)$ using 3 Degree of Freedom at 0.05 level of significance was 7.81. Since the $X^{2} c(3.74)$ is less than the $X^{2} t$ (7.81) the null hypothesis is within acceptable region; we should not reject the null hypothesis $(\mathrm{HO})$ : That the customer has no wiliness to repay loan.

- On Hypothesis 2

The Chi - square computed $\left(\mathrm{X}^{2} \mathrm{c}\right)$ from the respondents to the questionnaire in the above Chi-Square Contingency Table was $\mathbf{1 . 5 4}$ for hypothesis 2; while the Chi - square from the Statistical table $\left(\mathrm{X}^{2} \mathrm{t}\right)$ using 3 Degree of Freedom at 0.05 level of significance was 7.81. Since the $X^{2} c(1.54)$ is less than the $X^{2} t$ (7.81) the null hypothesis is within acceptable region; we should not reject the null hypothesis (HO): That the customer has no capacity to repay loan).

\section{D. - ON SECURITY}

Please tick the following: SA- Strongly agreed, A - Agreed, DA Disagreed; to bring out disadvantages of security on lending.

Table V: Disadvantages of security on lending

\begin{tabular}{|c|c|c|c|c|}
\hline S/N & STATEMENT & SA & A & DA \\
\hline 1 & Security is required just for the banker to play save & 18 & 2 & - \\
\hline 2 & Value of security offered may fall bellow facility required & 16 & 2 & 2 \\
\hline 3 & It is often times difficult to perfect legal mortgage & 18 & 2 & - \\
\hline 4 & Accurate valuation of security is always a challenge & 16 & 3 & 1 \\
\hline 5 & Security offered often run down - depreciated & 15 & 3 & 2 \\
\hline 6 & There is danger in executing the security & 18 & 2 & - \\
\hline
\end{tabular}

Sources: Researcher's field work

From Table V, the respondents were of the opinion that some of the defects of security to a lending banker are: The value of security offered may fall bellow facility required, that it is often times difficult to perfect legal mortgage, accurate valuation of security is always a challenge to the lending banker, Security offered often run down - i. e depreciation comes to play and there is danger in executing the security. 


\section{SUMMARY, CONCLUSION AND RECOMMENDATION}

In summary, the study examined the use of securities by the lending banker using Skye Bank Plc, Owo as the case study. The prerequisites for granting loans/facilities by the lending bankers were also examined.

The general conclusion that emerged from the above analysis of the respondents to the questionnaire administered were that:

- Despite the fact that bank customers have no ability to repay the loan approved to them, often times bank customers are not willing to repay the facility. Hence, the study deduced that before facilities are approved to customers the canon of lending (' $\mathrm{C}$ 's of lending): capital, capacity, character, condition and connection of potential borrowers must be critically evaluated by the banker who had been specially trained in lending procedures.

- The best form of bank security is the ability and willingness to repay the loan/facility and integrity of the customers. These qualities would spore bank debtors to repay the facilities granted to them as and when due.

- From the research it was evidently clear that the banker needs to evaluate the customers' accounts with the bank, as this would reveal the Turnover of the account and eventually helps in lending decision.

- The work revealed that bankers only ask for Security as an insurance against unforeseen developments and that security is only the last source through which the bank can get its money recouped should things turn sour.

- That the lending banker should never rely upon security as the primary source of loan repayment. Any facility granted to customer must be granted on the strength of the feasibility of the purpose for which facility is required - ability to repay vis-s-vis self liquidating. All lending applications must be so good that the question of security becomes secondary.

The empirical findings from this study revealed that the borrowers' Statement of Income and Statement of Financial Position should be analyzed and evaluated by the lending banker using these accounting ratios: Gearing ratio, Current ratio, Liquidity ratio, Stock Turnover ratio, Gross Profit ratio, Return on capital employed -ROCE, Earnings Per share - EPS and Earning yield. The study revealed that a careful analysis of these accounting ratios would be of good bases upon which the lending banker may use during the process of lending.

The empirical findings from this study also revealed that: Security to a banker is something to fall back on and to play safe should a bank customer default. Reasons why collateral securities are not reliable and dependable (Some Defects of Security) to a Banker are enumerated below: 
- The value of the security offered by a customer may be below the amount of the facility requested for.

- The security offered by the customer may be substandard e. g. Building constructed with inferior building materials.

- Perfection of security especially legal Mortgage always take very long time, expensive, laborious and cumbersome to conclude legal mortgage of any security offered any bank hence, it makes security pledged by the bank customers not to be effective when banks seek court action and foreclosure when customer defaults.

- Often times, accurate valuation of security is difficult.

- Running down of Asset and Asset depreciation is often witnessed by the banker.

- There are Dangers of execution or realization of the security by the lending banker.

- Preferential Creditors rank before other creditors in respects of the security pledged in the borrower's entity is to be liquidated.

- Finally, security can be set aside if created within three months of commencement of winding- up proceeding of a company.

\section{References:}

Adekanye F: (1986) Practice of Banking - Vol. 1 -Collins Ltd. p. 11. Adekanye F: (1986) Element of Banking in Nigeria, Third Edition Lagos: F \& A Publishers, p. 299.

Adekanye F: (1986) Practice of Banking - Vol. 1 - London Collins Ltd. p. 15.

Best, J. W. and Kahn, J. V. (1989) - Research In Education. $6^{\text {th }}$ Edition; New Delhi: $\quad$ Prentice- Hall India Private Ltd; P 141

David C: (1991) Success Element of Banking. Published by: John Murray Ltd. p. 217.

David C: (1981) Success in Element of Banking, Revised Edition, Great Britain: John Murray ltd., p 217.

Ituwe C.E: (1982) Elements of Practical Banking. Published by University Press Ltd. Ibadan.

Layi and Afolabi (1990) Law \& Practice of Banking 1990; Published by Top Golden Nig.

Ltd. Surulere Lagos. P. 232

Onanuga A. T and Oshinloye M. O. B. (1999); Practice of Banking; Published by Centre For Sandwich Programmes Ogun State University.

Perry F.E.: (1979) The Elements Banking, Second Edition; Great Britain: Chancer Press, p. 215. 